\title{
Pedro José Velarde: un rapsoda callejero en el México del siglo XVIII
}

Salvador Bernabéu Albert

EEHA, CSIC

Gracias al proceso abierto por la Inquisición mexicana en 1768 podemos reconstruir parcialmente la vida y la obra de Pedro José Velarde, poeta callejero que se hizo famoso en el mercado del Baratillo. Algunas de sus composiciones fueron dedicadas a ensalzar las actividades de los jesuitas, expulsados en 1767, por lo que fue encarcelado y sentenciado a servir durante tres años en el hospital de San Juan de Dios. Murió en 1784 en la pobreza.

PALABRAS CLAVE: cultura popular, poesía, jesuitas, inquisición, literatura colonial.

The Inquisition trial of Pedro José Velarde in 1768 reveals the life and works of this street poet that was very popular in the market of El Baratillo. Velarde was imprisoned because some of his compositions were dedicated to praise the activities of the jesuits, expelled in 1767. He was sentenced to three years in prison serving in the San Juan de Dios Hospital, but died in poverty in 1768.

KEYWORDS: popular culture, poetry, jesuits, inquisition, colonial literature.

Pedro José Velarde (1718?-1784), conocido en la capital novohispana con el apodo de El Poeta, formaba parte de la clase más baja de la sociedad: el vulgo, que el capuchino Francisco de Ajofrín describiese como: "despilfarrado y andrajoso, que lo afea y mancha todo, causando espanto a los recién llegados de España". ${ }^{1}$ A pesar de su calidad de español, la miseria lo había llevado a una situación penosa. Nacido en la ciudad de México hacia 1718, Pedro José era hijo de Juan Velarde y María Rivero. Nada sabemos sobre su infancia y juventud, pero ciertos conocimientos teológicos — vertidos en una poesía - quizás sean indicios de que estudió en alguna

1 Ajofrín, Fray Francisco: Diario del viaje que hizo a la América en el siglo XVIII, Instituto Cultural Hispano-Mexicano, México, 1964, vol. 1. pág. 77. Un fragmento del romance de Velarde, denunciado por la Inquisición, fue reproducido en la obra dirigida por Rivas Palacio: México a través de los siglos, Espasa, Barcelona, 1900, t. II, pág. 847. Más datos sobre El Poeta en Toribio Medina, José: Historia del tribunal del Santo Oficio de la Inquisición de México, Santiago de Chile, Imprenta Elzeviriana, 1905, págs. 368 y 427. 
escuela religiosa o, incluso, en el seminario. ${ }^{2}$ En 1768, con medio siglo a sus espaldas, su aspecto físico era deplorable: Velarde era muy flaco, narigón, trigueño, de mediano cuerpo, tenía las ropas a jirones y el pelo sucio y desaliñado. ${ }^{3}$ Junto a una situación económica precaria, también padecía ciertas dolencias: una relajación en la ingle izquierda y "un mal de corazón o epilepsia, que le embarga los sentidos y ofusca el juicio". ${ }^{4}$ Sus escasos ingresos económicos solo le permitían ocupar un cuarto modesto en el número 13 de la calle de Santa Clara, donde vivía con su esposa: una jovencita de dieciocho años de edad, huérfana y desamparada, de calidad castiza, con la que tenía una criatura de corta edad. ${ }^{5}$

Velarde se ganaba la vida escribiendo papeles de súplicas, cartas, parabienes de desposados, felicitaciones, congratulaciones de paridas, loas a las festividades de María Santísima y otros escritos que nos revelan un universo de sociabilidades (públicas y privadas) y de cultura del manuscrito en la capital virreinal. Además, realizaba diversos empleos menores en los tianguis o mercados capitalinos (recados, pequeños transportes y cuidado de cajones), y componía coplas sobre las últimas novedades ocurridas en el virreinato, que vendía por dos reales, actividad que le otorgaba cierta popularidad en uno de los lugares privilegiado de la marginalidad mexicana, el Baratillo:

"La famosa plaza del Baratillo - escribió fray Francisco de Ajofrín— es el concurso célebre de todos los leperos y zaragates de Méjico; es la universidad de los zánganos y zaramullos, donde, siendo su catedrático de Prima el bien conocido Pancho Moco, aprenden cuantos ardides y sutilezas hay para hurtar, sin poder ser acusados ni conocidos; dejándose atrás cien leguas, o por mejor decir, más de dos mil, a cuantos

2 Desconocemos cuándo y dónde aprendió a leer y escribir, pero en la poesía "Sobre la frecuencia de los sacramentos" cita al "Angélico Doctor" (Santo Tomás de Aquino) y la "mística doctora" (Santa Teresa de Jesús). Las coplas que se han conservado muestran un nivel cultural más que notable para la época, a lo que había que unir una buena consideración personal ("y me queda el dolor de lo que se presumirá de mí, siendo yo tan conocido en México por mi ejercicio"), aunque durante el proceso abierto por la Inquisición mexicana en 1768 se autocalificase de "vil infame gusano arrastrado" El original del proceso se encuentra en el Archivo General de la Nación de México (AGN en adelante), Expediente formado a petición del Sr. Fiscal contra Pedro José Velarde, vecino de esta ciudad, poeta, Inquisición, 1522, exp. 3. A él aludiremos constantemente en este estudio de caso, que pretende ofrecer una visión de la expulsión de los jesuitas de México en 1767.

3 Los médicos le diagnosticaron una "relajación de la ingle del lado siniestro". Véase el certificado de los cirujanos Juan Antonio Xarillo y Matheo Eugenio de la Fuente. México, 27 de noviembre de 1768. En AGN, Inquisición, 1522, exp. 3, ff. 55r.-v.

4 Estas últimas palabras, del propio Velarde, fueron desmentidas por los médicos de la Inquisición; no así la relajación de la ingle, que le causaba dificultades para andar.

5 Al parecer, antes había estado casado con otra jovencita, ya fallecida. 
maestros ha habido y hay en el Lavapiés y Barquillo de Madrid. Es materia larga escribir los enredos y sofisterías del Baratillo. Vea el que pueda sus constituciones, que andan manuscritas, y se divertirá con su bello método y salado estilo; allí se descifran todas las habilidades de los zaragates, léperos, zaramullos, pelagatos, zánganos y leperuscos, con los demás insignes profesores de esta famosa escuela". ${ }^{\circ}$

Situada "delante de la Catedral", 7 la plaza del Baratillo (nombre originado por la venta de productos a menor precio) era uno de los lugares más populares de la capital. En ella ofrecía El Poeta sus versos cuando el hambre le apretaba. Entonces, sacaba copia de composiciones originales, que ponía a buen recaudo, y se paseaba por el mercado vendiendo sus coplas. El comprador era variado: desde los mismos dependientes del Baratillo a sacerdotes y frailes, que no dudaban en adquirir las composiciones a pesar de lo atrevido de algunos temas. Velarde tenía clientes fijos, incluso llegó a escribir versos para uno de ellos: el cura de Coyoacán. Según confesó a los inquisidores que lo detuvieron, componía versos desde 1755. El tema de sus poemas eran las novedades de la colonia, únicos temas que compraban los clientes. Según Velarde: "no hay gente más novelera que la desta tierra y sólo pedían y piden lo nuevamente sucedi-

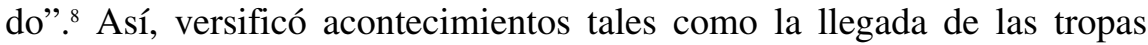
militares procedentes de la península a México, ${ }^{9}$ los continuos terremotos, la epidemia de sarampión (1761-1762) ${ }^{10}$ la frecuencia en la comunión y

6 Ajofrín: Diario del viaje ..., pág. 77. Sobre poesía y marginalidad, véase Lara Garrido, José: Alonso Álvarez de Soria, ruiseñor del hampa (vida en literatura de un barroco marginal), Litoral, Málaga, 1987.

7 González Polo, Ignacio (trascripción, introducción y notas): Reflexiones y apuntes sobre la ciudad de México (Fines de la colonia), Departamento del Distrito Federal, México, 1984, pág. 62. El Baratillo sobrevivió hasta 1792, año en el que fueron prohibidos sus puestos y mesillas. Véase Olvera Ramos, Jorge: "La disputa por el espacio público: los comerciantes y vendedores de la Plaza Mayor", en Aguirre Naya, Carlos, Dávalos, Marcela y Ros, María Amparo: Los espacios públicos de la ciudad. Siglos XVIII y XIX, Casa Juan Pablos-Instituto de Cultura de la Ciudad de México, México, 2002. págs. 84-97.

8 "Expediente formado ..." AGI, Inquisición, 1522, exp. 3, f. 64v. Uno de los testigos, José Navarro, declaró que creía que Velarde era el autor: "porque a cualquiera novedad sale con coplas que él compone según dice" (f. 6r).

9 La llegada de tropas a México se intensificó tras la derrota española en la Guerra de los Siete Años. El libro que sigue como referencia es Archer, Christon I: El ejército en el México borbónico, 1760-1810, FCE, México, 1983. Los soldados, muchos de ellos extranjeros, causaron numerosos problemas a la Inquisición y a los vecinos de los pueblos y villas donde se asentaban.

10 En septiembre de 1761 se produjo un grave brote de tifo, que se extendió por la capital y buena parte de las provincias del virreinato. La primera víctima se enterró el $1^{\circ}$ de septiembre y se extendió por todo el año siguiente. Alzate calculó los fallecidos “por lo menos 25000”. En Cooper, Donald B.: Las epidemias en la ciudad de México, 1761-1813, IMSS, México, 1980, pág. 75. 
la expulsión de los jesuitas. Esta versificación de los sucesos sitúa a Velarde en una larga tradición hispánica que se remonta al romancero popular y a los pliegos de cordel. El poeta (el coplero) se beneficia de la novedad para interpretarla de acuerdo a moldes literarios que comparte con sus lectores. El acontecimiento se versifica al gusto literario de los lectores-oyentes utilizando un mundo referencial e imaginativo que todos comparten. Las composiciones poéticas se venden manuscritas, pero su difusión es principalmente oral: se leen en reuniones y tertulias de amigos, como aparece en distintos momentos del proceso que le fue abierto en 1768 .

Como en otras épocas históricas, los poetas callejeros novohispanos tenían mala fama. Y en el caso de Velarde se unía, a un aspecto desarreglado, cierta fama de pedigüeño. Al divisar a algún conocido, lo asaltaba solicitándole una limosna o la compra de alguna de sus composiciones. El padre filipense Pedro José Rodrigo señaló: "que el expresado Velarde es hombre de ideas exóticas y poco dignas de atención, como porque en las veces en que por acaso me saludaba, dirigía siempre sus relaciones a fin de solicitar algún socorro a sus indigencias". ${ }^{11}$ Pero todas estas circunstancias no hubieran causado problemas a nuestro poeta si no hubiera cometido una indiscreción: el versificar la expulsión de los jesuitas, suceso acaecido en la madrugada del 24 de junio de 1767 por orden terminante de Carlos III. ${ }^{12}$ La expatriación de los padres fue un acontecimiento en todo el virreinato, y Velarde aprovechó el suceso para componer y vender varias coplas, desoyendo el edicto del virrey marqués de Croix con el que se anunciaba la expulsión:

"con la prevención de que, estando estrechamente obligados todos los vasallos de cualquiera dignidad, clase y condición que sean a respetar y obedecer las siempre justas resoluciones de su soberano, deben venerar, auxiliar y cumplir ésta con la mayor exactitud y fidelidad, porque S. M. declara incursos en su real indignación a los inobedientes o remisos en coadyuvar a su incumplimiento y me veré precisado a usar del último rigor y de ejecución militar contra los que en público o secreto hicieren con este motivo conversación, juntas, asambleas, corrillos o discursos de palabra o por escrito, pues de una vez para lo venidero deben saber los súbditos del gran monarca

11 Certificado de Pedro José Rodríguez, México, 15 de septiembre de 1768. "Expediente formado ...", AGN, Inquisición, 1522, exp. 3, f. 51v.

12 St. Clair Segurado, Eva María: "La expulsión de los jesuitas de América. Reflexiones sobre el caso de Nueva España”, en Gómez Díez, Francisco Javier (coord.), La Compañía de Jesús en la América Española (siglos XVI-XVIII), Universidad Francisco de Vitoria, Madrid, 2005, págs. 165-204. 
que ocupa el trono de España que nacieron para callar y obedecer, y no para discurrir ni opinar en los altos asuntos del soberano". ${ }^{13}$

Por supuesto, la orden de "callar y obedecer" no se cumplió. El impacto de este acontecimiento extraordinario en el virreinato fue enorme, pues los jesuitas poseían una amplia red de colegios, iglesias, residencias, haciendas y misiones, regían numerosas conciencias y sus enseñanzas se extendían desde los hijos de los virreyes a los indios más pobres y aislados del Noroeste de la Nueva España. Llegados al virreinato en 1574, los miembros de la Compañía de Jesús se situaron, en pocos años, a la cabeza de la educación novohispana, lideraron la pastoral urbana y lograron extender la frontera misional en el Septentrión con una rapidez vertiginosa, ocupando grandes áreas con escasa presencia hispana en el Norte: California, Sonora, Sinaloa, Nayarit, Tepehuanes y la Tarahumara. Al ser expulsados en 1767, los ignacianos contaban con 123 misiones, 25 colegios, 11 seminarios y cinco residencias. De los cerca de 600 jesuitas establecidos en México, un alto porcentaje era criollo. No todo había sido triunfos y parabienes en la expansión de la Compañía, pues en su desarrollo había cosechado numerosos enfrentamientos y conflictos con otras órdenes religiosas, los obispos, las universidades, las comunidades indígenas, los cabildos, los nobles, los comerciantes y los capitanes de los presidios fronterizos. Y ello explica que su expulsión desencadenara opiniones a favor y en contra.

El acontecimiento, por tanto, era candidato a la "poética de la realidad", pues las novedades prendían rápidamente en la tediosa vida de la colonia. A sus gentes les gustaba lo extraordinario, lo terrorífico y lo dramático. Pero, además, el bando que acompañó a la expulsión, con un lenguaje duro y represor ("de una vez para lo venidero deben saber [...] que nacieron para callar y obedecer, y no para discurrir ni opinar en los altos asuntos del soberano") tuvo el efecto contrario: aumentó las expectativas. Muchos novohispanos acudieron a los colegios, templos y residencias ignacianas, públicamente se lamentaron de su partida, a pesar de las numerosas tropas que los custodiaban, y obligaron a las autoridades a cambiar los itinerarios de los convoyes de jesuitas que, procedentes de las misiones y ciudades del interior, se dirigían al puerto de Veracruz. Las autoridades temie-

13 El bando completo se encuentra en Martín, Norman F.: Instrucciones del virrey marqués de Croix, Jus, México, 1960, págs. 22-23; y Navarro García, Luis: "El marqués de Croix”, en José Antonio Calderón Quijano (dr.), Los virreyes de la Nueva España durante el reinado de Carlos III, EEHS, Sevilla, 1967, t. I, págs. 159-381: 264-265. 
ron que la cercanía de los padres provocase manifestaciones de devoción y nuevas sublevaciones de los vecinos. ${ }^{14}$

Los novohispanos se levantaron en varias ciudades del obispado de Michoacán con presencia jesuita (San Luis de la Paz, Guanajuato, San Luis Potosí y Pátzcuaro) y en otras que no (Apatzingán, Guadalcázar, San Sebastián Agua del Venado, San Jerónimo de la Hedionda y San Felipe). En las primeras, grupos amotinados impidieron la salida de los padres. $\mathrm{La}$ expatriación de los jesuitas se retrasó durante varias semanas, y esta situación, insostenible para el virrey Croix, provocó la organización de una expedición militar, encabezada por el visitador general José de Gálvez, que restituyó el orden con la ayuda de varios patricios criollos, que en algunas ciudades ya habían controlado a los alzados. ${ }^{15}$ La pacificación se cimentó en numerosas ejecuciones sumarias, destierros y demolición de sus domicilios. Mientras tanto, los descontentos de la capital y Puebla, ya sin los jesuitas, pero con su recuerdo muy vivo, divulgaron profecías, escribieron sátiras y libelos, e imprimieron imágenes religiosas con leyendas a favor de los jesuitas. ${ }^{16}$ Sin conocerse las causas de la grave decisión real, bajo el peso del silencio impuesto, la expulsión era susceptible de utilizarse como tema de exaltación de la Compañía, de propaganda de sus méritos y, paralelamente, de crítica al gobierno y a sus reformas sociales y económicas. La voz de los contrarios se dejó sentir sin tapujos, provocando las iras de los principales acusados: el virrey, el arzobispo Lorenzana, el obispo de Puebla, Francisco Fabián y Fueros, y el visitador general José de Gálvez. Mientras este último estaba fuera con la expedición militar, la capital se llenó de versos satíricos. Uno de ellos apareció en la puerta del arzobispado con los siguientes versos: "La Iglesia está viuda, sin manto ni toca, porque la gobierna, Pachita la loca”. Durante el otoño de 1767 surgió una virulen-

14 Los jesuitas fueron sacados de la capital en pocos días, pero la "expulsión" de la Nueva España se dilató por dos años. Un convoy procedente de Filipinas atravesó el virreinato entre el 20 de enero y el 17 de febrero de 1770. Véase St. Clair Segurado, Eva María: "Arrestos y conducción a Veracruz de los jesuitas mexicanos", en Jiménez López, Enrique (ed.): Y en el tercero perecerán. Gloria, caída y exilio de los jesuitas españoles en el s. XVIII, Universidad de Alicante, Alicante, 2002, págs. 221-249; y Lorenzo García, Santiago: La expulsión de los jesuitas de Filipinas, Universidad de Alicante, Alicante, 1999, págs. 149-150.

15 Sobre las rebeliones, véase Castro Gutiérrez, Felipe: Nueva ley y nuevo rey. Reformas borbónicas y rebelión popular en Nueva España, El Colegio de Michoacán-UNAM, México, 1996.

16 Sobre estas manifestaciones de apoyo a la Compañía, véase Felipe Castro Gutiérrez: "Profecías y libelos subversivos contra el reinado de Carlos III", Estudios de Historia Novohispana, México, nº 11, 1991, págs. 85-96; y Alanis Enciso, Fernando Saúl: “Todos herejes: expresiones de descontento en la Nueva España ante la expulsión de la Compañía de Jesús, 1767-1768”, Colonial Latin American Historical Review, New Mexico, vol. 9, n² 2, Spring 2000, págs. 209-242. 
ta literatura clandestina, pero ninguna causó más inquietud que la antipatoral "Quis ergo nos separavit a charitate Cristi", en donde se invitaba a la desobediencia al rey y se defendían las enseñanzas jesuitas. ${ }^{17}$

Para reprimir esta literatura clandestina, el virrey solicitó la ayuda de los inquisidores. En carta del 24 de noviembre de 1767 les pidió que recogiesen los numerosos papeles y libelos que circulaban por la ciudad. La respuesta negativa del Santo Oficio ${ }^{18}$ provocó la ira de Lorenzana y del marqués de Croix. Los inquisidores aludieron al "silencio" impuesto por el trono para hablar a favor o en contra de la expulsión, y éstos consideraron la inactividad como un apoyo velado a los descontentos y una falta grave. Para zanjar la cuestión, ambas partes remitieron la cuestión a Madrid. La respuesta no llegó hasta el 12 de junio de 1768, dilación que aprovecharon algunos contrarios a la expulsión para seguir difundiendo sátiras y libelos. El Supremo Consejo de la Inquisición, en carta fechada el 21 de marzo de 1768, reprobó la inactividad de los inquisidores mexicanos, señalando que había visto con gran dolor y desagrado la excusa en su actuación y la desaprobaba "en todo y por todo". ${ }^{19}$ Para que no se produjesen más retrasos, la Suprema les mandó imprimir y distribuir sin demora un texto condenatorio que acompañaba la misiva.

Impresas trescientas copias, fueron fijadas en los lugares habituales el 17 de junio, no tardando en aparecer las denuncias y las entregas de textos publicados y manuscritos, muchos de ellos llegados de Europa. En él se reprobaban en general todos los papeles satíricos, rechazaba expresamente la anti-pastoral "Quis ergo nos separavit" y se mandaba recoger una estampa sediciosa con la imagen de San Josaphat. El éxito de la campaña inquisitorial contrastó con el escaso éxito de una iniciativa virreinal anterior: un bando del 26 de noviembre de 1767 que prohibía los papeles y libelos sacrílegos y declaraba reos de lesa majestad a los que los compusiesen y esparciesen..$^{20}$

17 La anti-pastoral se encuentra en el Archivo General de Indias (AGI en adelante), México, 1365 .

18 La carta fue firmada por Cristóbal Fierro, González de Andia y Julián Amestoy.

19 Copia de carta de Francisco, arzobispo de México, al excelentísimo señor marqués de Croix, México, 24 de noviembre de 1767. AGI, Mexico, 2778.

20 El texto decía: "impongo a todos perpetuo y absoluto silencio para que en lo sucesivo ninguno sea osado a escribir, ni hablar públicamente o secretamente sobre la expulsión de los jesuitas”. El bando recuerda mucho al editado el día de la expulsión. El mismo discurso autoritario y la misma gravedad en la consideración de los desobedientes: Lesa Majestad. "Expediente sobre el oficio pasado a este tribunal por el señor virrey marqués de Croix a fin de que prohibiese por un edicto los papeles 


\section{La denuncia}

El 20 de julio de 1768, Ignacio Estevez ${ }^{21}$ llevó al bachiller Andrés López Barba, nuncio del tribunal del Santo Oficio, un cuaderno de coplas sobre la expulsión de los jesuitas que comenzaba: "A la arma, al arma" y terminaba con las palabras "a gusto mío". Lo había adquirido ocho meses antes (noviembre de 1767) al Poeta del Baratillo, quien le comunicó que la composición era de su autoría. En el momento de la compra estaba acompañado de otros dos vecinos y parientes: Manuel y José Navarro, quienes vendían frenos y productos de hierro también en el Baratillo. ${ }^{22}$ Este último tenía cierta relación con el rapsoda del mercado (en una ocasión le dejó varias composiciones en empeño, que rompió el mismo día), pero ninguno de los tres testigos conocía el nombre ni los apellidos del coplero. Por ello, cuando el inquisidor fray Franciso Larrea les tomó declaración, los testigos de cargo dieron las señales físicas del poeta y su lugar habitual de venta, pero no su nombre. En el interrogatorio, celebrado el 21 de julio, el citado Estevez aseguró que había adquirido el poema para divertirse y que, tras conocer el edicto del último domingo, lo llevó al Santo Oficio porque el papel "hablaba contra el Rey"; añadiendo que la delación no había sido movida por el odio, sino por el descargo de su conciencia. ${ }^{23}$

Gracias a los interrogatorios de los dos testigos de la compra (Manuel y José Navarro), se descubrieron otros datos interesantes: primero, que $E l$ Poeta había declarado que escribió las coplas para el cura de Coyoacán y que lo buscaban muchos clérigos y seglares aficionados; segundo, que el coplero se jactaba públicamente de que, llamado por el Santo Oficio en cierta ocasión, había salido bien librado, y, tercero, que en la venta, suce-

\footnotetext{
y libelos que decía haberse difundido en esta ciudad y provincias contra los reales decretos de $\mathrm{Su}$ Majestad, su pragmática sanción para la expulsión de los padres jesuitas, las providencias de su excelentísima arregladas a ella y contra las cartas pastorales de los ilustrísimos arzobispos de esta metrópoli y obispos del reino". AGN, Inquisición, 1521.

21 Ignacio Estevez era español, casado, de 30 años de edad, vecino de México y de profesión gamucero.

22 Manuel Navarro, de 31 años de edad, era español, casado, vecino de México y de oficio peluquero; mientras José, también español y residente en México, tenía 28 años.

23 El 21 de julio, el nuncio López Barba enseñó el cuaderno al inquisidor decano, el licenciado Julián Vicente González de Andia y al inquisidor licenciado Julian de Amestoy, quienes consideraron que las coplas eran de las "circunstancias y calidades" expresadas en el último edicto publicado. El primer paso del proceso fue la remisión del cuaderno al padre maestro Francisco Larrea, dominico, calificador y comisario del Santo Oficio, el citado 21. Y el mismo día interrogó a Ignacio Estevez en el convento imperial de Santo Domingo de la ciudad de México. Un día más tarde repitió el examen con Manuel Navarro, y el día 23 con José Navarro.
} 
dida durante una siesta, Velarde habló "quedito" para que no lo oyeran unos soldados que estaban cerca: "a causa de que las coplas eran contra el rey", ${ }^{24}$ es decir, que el autor era consciente de la gravedad del tema de la composición.

Ante la trascendencia de las informaciones (y sin duda queriéndose congraciar con el virrey y con la corte), los inquisidores averiguaron el nombre del poeta y el 28 de julio nombraron a dos franciscanos: fray Nicolás Antonio García y fray Pablo Antonio Pérez, para que censurasen los versos. En el informe, rubricado el 3 de agosto, calificaron el cuadernillo de coplas de sedicioso, satírico, temerario y destructivo de la paz y la quietud del reino, y a su autor de: "dementado, inquieto y faccionario, detestable, que intenta intimidar a los incautos, llamando su atención para el ascenso con fabulosos monumentos de aparente devoción a los P. Jesuitas". ${ }^{25}$ En consecuencia, el 11 de agosto, el inquisidor Julián Vicente González de Andia acusó a Velarde de graves delitos contra el Estado y la religión, y ordenó su detención y el embargo de sus bienes. ${ }^{26}$ Una semana más tarde, el poeta fue detenido dentro de una iglesia, en donde se había refugiado, y entregado a las cárceles secretas por no haber cárcel pública. El alguacil y sus ayudantes que lo prendieron no pudieron embargarle nada, pues nada tenía. Al conocer la noticia, el inquisidor González de Andía señaló, entre risas: "que qué se podía esperar de tal sujeto y su oficio", ${ }^{27}$ y es que los poetas callejeros nunca salieron de pobres.

En el primer interrogatorio que Velarde tuvo con el inquisidor González de Andia, el 22 de agosto, declaró que pensaba que su compare-

24 Testimonio de los interrogatorios realizados el 22 y el 23 de julio, en "Expediente formado ...", AGN, Inquisición, 1522, exp. 3, ff. 4v-6v. Las ratificaciones se realizaron el 1, 2 y 3 de agosto ( $7 \mathrm{v}$ 9r). En el segundo interrogatorio, además de fray Francisco Larrea, estuvieron presentes los también dominicos fray Manuel Lozano y fray Mariano Ponce de León.

25 La censura de fray Nicolás Antonio García y fray Pablo Antonio Pérez, fechada en el convento de San Francisco de México, el 3 de agosto de 1768, en "Expediente formado...", AGN, Inquisición, 1522, exp. 3, ff. 15v-16r.

26 El inquisidor fiscal del Santo Oficio, licenciado Amestoy, señaló que los versos de Pedro José Velarde fueron calificados de sediciosos por los reverendos padres calificadores, y no menos injuriosos a las acordadas resoluciones reales que el "papel anterior" prohibido en el último edicto del 17 de julio de 1768, y que por ello resulta "reo de Estado y contra la religión". En consecuencia, pide y suplica que se sirva librar mandamiento de prisión con embargo de bienes contra el referido Velarde, sea reducido a las cárceles secretas y "se le siga su causa como las demás de Fe". Secreto de la Inquisición de México y agosto 8 de 1768. "Expediente formado...", AGN, Inquisición, 1522, exp. 3 , f. 37 r.

27 "Expediente formado...", AGN, Inquisición, 1522, exp. 3, f. 39r. Por no haber desocupada ninguna cárcel pública, Velarde se puso en depósito en cárceles secretas. 
cencia ante el Santo Oficio se debía: "para ver si los papeles que vende son buenos o malos", pero ni remotamente pensó que pudiera estar acusado de lesa majestad por unas coplas realizadas un año antes y que nadie pedía ya. Por eso, sorprendido, negó por dos veces que conociese las coplas que comienzan: "Arma, arma, guerra, guerra". Ni las había oído nunca ni conocía al autor. El inquisidor, entonces, le reveló el nombre del denunciante, Ignacio Estevez, y esta vez Velarde tuvo que retractarse y reconocer que era el autor de las coplas, añadiendo que las compuso para mantener a su joven esposa y que se valió de la gran novedad que causó la expulsión de los jesuitas: "pero que nunca tuvo ánimo ni se le pasó por la imaginación agraviar ni injuriar a su majestad católica ni a ninguno de sus ministros". Para demostrar su inocencia, entregó otra copla sobre el mismo tema de la expulsión de la Compañía que comienza: "A los que están caducando" y acaba: "tanta lástima lastima", y otras composiciones sobre la llegada de las tropas — donde alababa al rey—, el sarampión o la frecuencia en los sacramentos. Nada tenía que ocultar, pues su intención no era difamar la persona y las acciones del monarca. Se consideraba un buen súbdito, que sólo volcaba en versos las novedades del virreinato. En el interrogatorio, Velarde justificó su primera reacción de negar la autoría porque pensaba: "que se le había de pasar a otro tribunal en donde podía peligrar su vida". Sin duda tenía en mente los juicios sumarísimos que habían llevado a la horca a numerosos vecinos de San Luis de la Paz, Guanajuato y San Luis Potosí.

Además, Velarde señaló en su defensa que, cuando las hizo, no estaba publicado el edicto inquisitorial que las impedía. Pero González de Andia le recordó que este tipo de versos, además de estar prohibido en el Expurgatorio, había sido vetado en otros edictos del Santo Oficio que mandaban recoger "libros o papeles del tenor del suyo". Y así no podía desconocer dos que modernamente se habían publicado, prohibiendo las coplas, décimas y otros escritos en contra del arzobispo Rubio y las composiciones en contra el marqués de Esquilache y el motín de $1766 .{ }^{28}$ Por último, a la acusación de que se había jactado de haber salido bien de otra cita con el Santo Oficio, Velarde lo negó terminantemente, añadiendo que lo que

28 Las sátiras en contra del arzobispo Manuel Rubio Salinas por secularizar los curatos se encuentran en AGN, Inquisición, 945. Fueron editadas por Miranda, José y González Casanova, Pablo: Sátiras anónimas del siglo XVIII, FCE, México, 1953, págs. 97-104. Sobre los escritos, en prosa y verso, generados por el motín de Esquilache, véase Andrés-Gallego, José: El motín de Esquilache, América y Europa, CSIC, Madrid, 2003, págs. 600-606. 
dijo ante varias personas era: "que tenía que traer a este Santo Oficio un papel de pliego y medio o dos pliegos con una denuncia, que por vía de consulta llevó al padre Pedro José Rodríguez y Arispe, filipense, que parará en su poder y el declarante volverá a hacer cuasi en los mismos términos si se le da tintero y papel". ${ }^{29}$

Sin embargo, de nada le sirvieron a Velarde sus proclamas de amor a la Corona. La presión de las autoridades de Madrid y México sobre el Santo Oficio para descubrir a los autores de los anónimos en contra de la salida de los jesuitas hizo su efecto. El 26 de agosto de 1768, el licenciado Julián Amestoy, inquisidor fiscal del Santo Oficio, se querelló y acusó grave y criminalmente a Pedro José Velarde de: "reo perpetrador de graves crímenes y delitos, e incurso por ellos en censuras y otras muchas penas así corporales como pecuniarias establecidas (...) para que le sirvan de escarmiento y a otros de ejemplo". ${ }^{30}$ El fiscal recordó que la formación de libelos, coplas y romances infamatorios, sediciosos y satíricos era uno de los delitos más castigados por el derecho por lo perjudicial a la religión y al Estado, a la quietud pública y al honor de las personas: "creciendo de punto según los tiempos y circunstancias en que se divulgan y andan de mano en mano entre los émulos o poco afectos de ambas majestades". Y este sería uno de los delitos cometidos por El Poeta, quien: "tomó el diabólico intento de escribir, formar, vender y publicar no menos que en la plaza pública que llaman el Varatillo de esta corte el libelo y romance que empieza Arma, arma, guerra, guerra, muy difuso y dilatado, cuyo contexto se halla calificado de sedicioso y satírico, de temerario y destructivo de la paz y la quietud" que el Rey y consejo solicitan para su súbditos y leales vasallos. Además, se agrava la enormidad de dicho crimen y delito, teniendo presente el tiempo en que se difundió dicho romance, que fue con la pragmática sanción y reales resoluciones sobre la expulsión de los regulares de la Compañía y ocupación de sus temporalidades:

"por la que se veyan contristados los afectos y apasionados de dichos regulares de la Compañía, y tal vez llevarían a mal tan justa determinación y hablarían lo que se les antojase y dictase su propia inclinación contra la Sangrada Persona de Su Majestad Católica o sus ministros, y así ¿qué daño y ruina espiritual no habrá causado este reo con dicho su libelo y romance en los ánimos y almas de sus lectores y oyentes? No

29 "Expediente formado...", AGN, Inquisición, 1522, exp. 3, f. 43r.

30 AGN, Inquisición, 1043, ff. 298r-299v. Copias en "Expediente formado ...", AGN, Inquisición, 1522, exp. 3, ff. 46r-47v y 60r-61v. 
es fácil de ponderarse, y por eso corresponde la condigna punición y que en alguna manera se dé satisfacción pública en esta corte".

En consecuencia, Velarde debía ser castigado no solo con las penas contra los sacrílegos, perjurios y falsarios, sino también con las condenas establecidas contra los que delinquen en deshonor del Santo Oficio.

\section{La defensa del poeta}

Sin duda, Velarde fue una víctima de las circunstancias. El 27 de agosto, El Poeta compadeció de nuevo ante el inquisidor Julián Vicente González de Andía a petición propia, Le rogó dos cosas: la primera, que si su causa pasase a la justicia ordinaria, informase que fue prendido en una iglesia, y la segunda, que demandaba un examen médico, pues padecía una enfermedad de corazón que le había convertido en demente, como podría atestiguar el padre Pedro José Rodríguez de Arispe, de la Congregación de San Felipe Neri. Pero estas maniobras no le valieron de nada. Consultado el padre Rodríguez, señaló que: "el expresado Velarde es hombre de ideas exóticas y poco dignas de atención", ${ }^{31}$ y el 29 de agosto, en la audiencia de la mañana, González de Andía le leyó los graves delitos enumerados por el inquisidor Amestoy, dándosele copia para que preparase su defensa en colaboración con uno de los tres letrados que tenía el Santo Oficio: Juan José Azpeitia, Joaquín Blanca e Ignacio José de Villaseñor y Cervantes. Velarde eligió a este último y se le envió de vuelta a la cárcel con un pliego de papel "para los apuntes de su defensa".

La preparación de la defensa se demoró durante varios meses. Velarde y Villaseñor, acusado y letrado, obtuvieron traslado de la declaración de los testigos y certificados de los médicos, y prepararon un escrito, firmado por el primero, en el que se defendía de las acusaciones..$^{32}$ Las

31 Nota de Pedro José Rodríguez, México, 15 de septiembre de 1768, en "Expediente formado ...", AGN, Inquisición, 1522, exp. 3, f. 51v.

32 Defensa escrita de Velarde, en "Expediente formado...", AGN, Inquisición, 1522, exp. 3, ff. 62r-65v. El 11 de enero de 1769, el inquisidor Andía llamó a Velarde y, a la pregunta de qué traía acordado, dijo: "Que no trae acordado cosa alguna". Conferenciaron, y Villaseñor leyó al preso lo que traía para presentar en su defensa: No haber palabra o expresión directa o inmediata en contra del rey; su venta en la plaza pública (de lo que se infiere no haber tenido concepto de que así en hacer como en vender se oponía a las acordadas determinaciones de nuestro soberano); que uno de los testigos era interesado, pues había tenido una reyerta con él; y que escribió las poesías por necesidad (AGN, Inquisición, 1522, exp. 3, ff. 73r-75r). El abogado del reo hizo bien su papel, presentando objeciones contra los jueces (recusación), alegando varias circunstancias atenuantes y mostrando que uno de los testigos de la acusación al menos tenía motivos en su contra. 
líneas de la defensa fueron cinco. En primer lugar, Velarde declaró ser fiel cristiano. Desde hacía tres años quería presentar sus versos a los inquisidores para que los censurasen y comprobar que estaban dentro de la recta doctrina. Enterado de su búsqueda por el alguacil, se refugió en un templo, de donde fue sacado a tirones. Por ello se sentía usurpado de la santa inmunidad.

En segundo lugar, Velarde alegó demencia transitoria, pues sufría "un mal de corazón o epilepsia, que le embarga los sentidos y ofusca el juicio", de forma que ha estado tiempo "adementado". Vicente Ignacio de la Peña Brizuela, médico de presos, después de visitarlo y reconocerlo, concluyó que no padecía ninguna especie de demencia, fatuidad o locura, ${ }^{33}$ mientras el filipense Pedro José Rodríguez solo agregó que: "su estilo no deja de indicar poca cordura", ${ }^{34}$ pero sin dar una clara resolución. Lo que sí certificaron los cirujanos Mateo Eugenio de la Fuente y Juan Antonio Jarillo es que sufría una hernia o "relajación en la ingle del lado siniestro". ${ }^{35}$

En tercer lugar, Velarde pretextó la necesidad de mantener a su joven mujer y a un hijo de corta edad para componer las coplas: escribía para subsistir. El Poeta se sentía un hombre desdichado debido a la miseria en que vivía y a los temores de que su esposa cayese en la deshonra: "la verdad, Señor, como mi esposa en niña es muy golosa y muy antojadiza y como está criando, acabado de desayunarse, acabado de comer, me decía que tenía hambre y yo temeroso de que el Diablo es muy sutil, sabe Dios que tantos días me he quedado en ayunas y sin comer porque a ella le alcanzara lo poco que adquiría". ${ }^{36}$ La composición y venta de coplas era la única forma de mantener a su familia, a pesar de que no era una actividad rentable: "también, digo que no solo en versos desta novedad buscaba yo mi vida, que ni todos son amigos de versos ni están los tiempos para esto, por-

33 El informe de Vicente Ignacio de la Peña y Brizuela, en "Expediente formado ...", AGN, Inquisición, 1522, exp. 3, ff. 53r-54v. México, 24 de octubre de 1768. En una primera entrevista, Velarde le intentó convencer de que anteriormente estuvo loco, pero, habiéndole señalado una cadena y otros instrumentos con los que se descubría si mentía o no, "respondió prontamente y con toda libertad que él nunca había estado loco ni fatuo, y que solo había tenido sus flatos, que con divertirse y salir de casa se le quitaban".

34 Consultado el padre Rodríguez, señaló que lo encontró preso en la cárcel de la corte, a donde iba a confesar, desnudo de medio cuerpo para arriba, haciendo extraordinarios virajes y, preguntado el motivo, "se me dixo que estaba demente", pero no sabe si antes o después lo ha padecido. Nota del padre Pedro José Rodríguez, México, 27 de septiembre de 1768. "Expediente formado ...", AGN, Inquisición, 1522, exp. 3, f. 49v.

35 Certificado de los cirujanos. "Expediente formado ...", México, 27 de noviembre de 1768, Inquisición, 1522, exp. 3, ff. 55r-55v.

36 Defensa escrita de Velarde. "Expediente formado...", AGN, Inquisición, 1522, exp. 3, f. 64r. 
que una comedia vale medio y no hay quien la quiera". ${ }^{37}$ Velarde había pedido ayuda a varios religiosos, aunque solo le habían socorrido con algunos reales y algo de comida, por lo que tenía que volver a componer versos: "y mas cuando Dios me dio este don para aprovecharme de él en mi suma miseria y necesidad".

En cuarto lugar, Velarde expuso la inquina de uno de los presuntos acusadores, al que habría ganado en una justa poética en el mismo Baratillo. Y, por último, alegó que compuso las coplas: "para quitar algunas hablillas que había, alegando unos a favor de los jesuitas, y otros en contra del rey, diciendo que era judío" ${ }^{38}$ Él solo se había limitado a exponer lo sucedido, añadiendo en uno de los versos que era vasallo real y que no impugnaba lo mandado por el rey. Estos dos últimos puntos son muy interesantes. Velarde, en colaboración con su abogado, va a tratar de eludir la acusación de actuar en contra del decreto regio, destacando que cumplió con los preceptos:

"respecto a que se reducía a dos puntos, que son estos: no se hable en contra ni en favor, que fue decir no se diga que fue bien hecho desterrar a los jesuitas porque entonces es dar a entender que quizá tuvieron algún delito grave; no se diga que fue mal hecho desterrar a los jesuitas, porque entonces resulta en agravio de las justas determinaciones de Su Majestad, que Dios guarde, y de sus prudentes ministros. Es así que yo no digo en mis poemas que fue bien hecho ni que fue mal hecho, luego no incurrí ni en la pena del bando ni en la censura de este Santo Oficio o edicto". ${ }^{39}$

No había tomado partido, por lo que era inocente. ${ }^{40} \mathrm{Y}$ tampoco aceptaba el cargo de "inquietar las conciencias", pues era común en el virreinato tanto el componer coplas como el hablar de la expulsión de los jesuitas. Sería injusto que cayese sobre él toda la culpa, cuando era corriente desde que se fijó el bando:

"hablar del asunto en las plazas, en las calles, hombres, mujeres, muchachos, indios e indias, y así nunca pensé que en mí resultara jamás causa tan grave como se me hace de cargo, pues, a saberlo, no hubiera hecho dichos versos ni por un millón de plata, ni los hubiera vendido en paraje tan público como el Baratillo, ni los hubiera dado por materia tan corta de dos reales para mantenerme, pues cuando todos hablaron, públi-

37 Defensa escrita de Velarde. "Expediente formado...", AGN, Inquisición, 1522, exp. 3, f. 64r.

38 Declaración de Velarde. 8 de noviembre de 1768. "Expediente formado...", AGN, Inquisición, 1522, exp. 3, f. 56r

39 Defensa escrita de Velarde. "Expediente formado...", AGN, Inquisición, 1522, exp. 3, f. 63v.

40 Defensa escrita de Velarde. "Expediente formado...", AGN, Inquisición, 1522, exp. 3, f. 64v. 
camente hablan y estarán hablando por sólo antojo nunca esperaba que lo que hice solo para diligencia resultara en causa tan grave contra mî", ${ }^{41}$

Esto era cierto, la expulsión había sido ampliamente comentada a pesar del bando del marqués de Croix. Los expedientes inquisitoriales que se guardan muestran hasta qué punto fue comentada la salida de los padres. Menos presumible era que Velarde tuviese la intención - aparte de comer y alimentar a su familia - de: "oponerme a las infames, mordaces, traedoras y sacrílegas opiniones de tantas y tan mal fundadas conversaciones que lastimaban los cristianos oídos, oyendo de unos agravios contra los padres; otros, contra nuestro padre Rey y Señor, que Dios guarde". El Poeta quiere erigirse en (falso) defensor de la actuación de Carlos III y concluye: "si un hijo obediente oye denhorrar a su padre, aunque su padre le haiga impuesto silencio, no puede menos que romperlo". ${ }^{42}$ Finalmente, Velarde pidió perdón y misericordia y volvió a declarar el amor al rey. Como muestra de su arrepentimiento y de su disponibilidad de colaborar con los inquisidores, enumeró varios usos erróneos de las estampas, los rosarios y las cruces en las calles de México. ${ }^{43}$

\section{La condena}

A pesar de la estrategia del letrado y de los votos de Velarde de servir a los enfermos de San Juan de Dios el resto de su vida y de escribir en adelante solo versos para loar a María Santísima, no quedó en libertad. El 9 de enero de 1769, los inquisidores mexicanos recibieron una carta de la Suprema de Madrid pidiéndole el expediente del caso para juzgarlo en la corte. Mientras tanto, el acusado debía permanecer en la cárcel. ${ }^{44}$ Así se hizo, sacando copia del sumario y enviándolo a España. Pero la respuesta no llegó en un tiempo prudencial y, ante la tardanza de noticias, los inquisidores novohispanos volvieron a escribir a la corte el 26 de septiembre de 1770 para saber noticias de la causa de Velarde. La respuesta causó sensación: las coplas no habían llegado con el expediente, y el inquisidor gene-

41 Defensa escrita de Velarde. "Expediente formado...", AGN, Inquisición, 1522, exp. 3, f. 64r.

42 Defensa escrita de Velarde. "Expediente formado...", AGN, Inquisición, 1522, exp. 3, f. 67r.

43 Defensa escrita de Velarde. "Expediente formado...", AGN, Inquisición, 1522, exp. 3, f. $65 \mathrm{r}-65 \mathrm{v}$.

44 “Expediente formado...", AGN, Inquisición, 1522, exp. 3, f. 76r-76v. 
ral les ordenó que: "en atención al tiempo que está preso, os encargo le despachéis con la brevedad posible, administrando justicia según lo permita el estado y méritos de su causa". ${ }_{45}$

Finalmente, tras las dilaciones, el proceso y causa de Velarde se resolvió el 6 de mayo de 1771 con la conminación severa para que en lo sucesivo se abstuviera de componer y vender coplas: "de la calidad y naturaleza de las que han dado motivo a esta causa o de otra cualquiera que pueda tener alusión con ella" y, en consideración al período de cárcel en que estuvo, fuese recluido en el convento de San Juan de Dios durante tres años para atender a los enfermos. La sentencia definitiva, datada el 7 de mayo de 1771, está firmada por los inquisidores González de Andía, Manuel Ruiz de Vallejo y Dionisio de Rocha.

Internado en el hospital de San Juan de Dios, Velarde gozó de gran libertad y de la visita diaria de su esposa y su hijo. Todos comían de la ración que le daban. Pero no estaba satisfecho, porque los frailes le impedían que su mujer se quedase a dormir en la enfermería. Así, enojado, el primero de junio de 1771 salió a vender un sombrero para darle el importe a su consorte y no regresó durante algunos días. Un mes más tarde, Velarde escribió a los inquisidores ${ }^{46}$ quienes fueron sensibles a su demanda de estar con su esposa. Por ello escribieron al padre prior de San Juan de Dios para solicitarle que El Poeta pudiese comunicarse con su mujer con moderación. La situación quedó resuelta momentáneamente, pues la tarde del 24 de diciembre de $1771,{ }^{47}$ Velarde se marcho de nuevo. Su rastro desapareció durante años, hasta que el 8 de febrero de 1784, postrado en una cama del hospital de San Andrés y sintiéndose próximo al final de la vida, confesó a sus enfermeros que llevaba doce años fugitivo. Enterado el Santo Oficio, mandó una carta para que el director del hospital averiguase más cosas, pero El Poeta murió el 9 de febrero. ${ }^{48}$ Un triste final para el rapsoda del Baratillo, pero como escribió José Emilio Pacheco: "En la poesía no hay

45 La carta del inquisidor general, fechada en Madrid el 11 de enero de 1771, llegó a México el 30 de abril siguiente. "Expediente formado...", AGN, Inquisición, 1522, exp. 3, f. 63v.

46 En la carta, Velarde denunció al enfermero fray Ignacio de Escobar por leerle al padre Girón: "unos versos totalmente sediciosos y mordaces, heréticos contra Su Majestad". "Expediente formado ...", AGN, Inquisición, 1522, exp.3.

47 El dominico fray Ignacio Escobar esperó hasta después de las fiestas pascuales, pero, viendo que no regresaba, lo comunicó a los inquisidores en carta del 10 de enero de 1772. "Expediente formado ...", AGN, Inquisición, 1522, exp 3.

48 El 10 de febrero, el rector del citado hospital, José Quintanilla. comunicó su fallecimiento y adjuntó un certificado de que murió el 9 de febrero de 1784. "Expediente formado ...", AGN, Inquisición, 1522, exp. 3. 
final feliz / Los poetas acaban / viviendo su locura. / Y son descuartizados como reses / (sucedió con Darío). / O bien los apedrean y terminan / arrojándose al mar o con cristales / de cianuro en la boca. / O muertos en el alcoholismo, drogadicción, miseria. / O lo que es peor: poetas oficiales, / amargos pobladores de un sarcófago / llamado Obras Completas". ${ }^{49}$

\section{La obra del poeta}

Gracias al proceso abierto por la Inquisición en 1768 conocemos algunas de las composiciones de Velarde, que transcribimos en la segunda parte de este trabajo. En primer lugar he colocado los versos dedicados a la expulsión de los jesuitas. El poema más importante - pues causó la denuncia y la detención- es el que se inicia "Arma, arma, guerra, guerra", pero hay otra tres composiciones más: "Fue la Compañía non plus"; "A los que están caducando" y el soneto que empieza: "Que crea de los jesuitas lo que veo". En ellos muestra su devoción por los ignacianos y se lamenta de su partida. A continuación, aparece una colección de breves composiciones laudatorias al rey de España. Los versos cantan el celo del monarca por el envío de las tropas al virreinato para defenderlo de sus enemigos. Estas composiciones fueron muy importantes para su defensa, pues permitieron demostrar su amor y devoción al monarca. Por último, transcribo dos interesantes poemas, el primero dedicado al sarampión y el segundo a cantar los beneficios espirituales de la frecuencia del sacramento de la comunión. Esta práctica era defendida por los jesuitas y otras órdenes frente al clero jansenista, orientación en la que fueron englobados el arzobispo Lorenzana y otros obispos novohispanos. Conocemos por el proceso los temas de otros versos (terremotos, a la amenaza de los piratas), pero se han perdido. Esta literatura popular de la colonia es de difícil conservación, por ello, los archivos de la Inquisición se han convertido en un filón excelente. ${ }^{50}$

49 Pacheco, José Emilio: En resumidas cuentas. Antología, edición de Hernán Sánchez, Visor, Madrid, 2004, pág. 55. El poema se titula "Vidas de los poetas".

50 Trabajos pioneros fueron los de Toribio Medina: Historia del tribunal del Santo Oficio de la Inquisición de México, Santiago de Chile, Imprenta Elzeviriana, 1905; Lina Pérez-Marchand, Monelisa: Dos etapas ideológicas del siglo XVIII en México a través de los papeles de la Inquisición, El Colegio de México, México, 1945; y la edición preparada por Miranda y González Casanova: Sátira anónima... Las investigaciones se han incrementado tras la aparición del magnífico Catálogo de textos marginados novohispanos. Inquisición: siglos XVIII y XIX. Archivo General de la Nación (México), Archivo General de la Nación-El Colegio de México-UNAM, México, 1992. Este trabajo, fruto del 
Durante el siglo XVIII, las coplas llenaron la capital virreinal. Velarde lo señala con claridad. Los versos estaban presentes tanto en las calles como en las reuniones de las personas de distinción: "en los fandangos de la plebe ya no se oye otras coplas y versos que de esta naturaleza, ni se haya otra cosa en el Portal del Santo Ecce Homo de esta ciudad". Otro punto de venta era el puente del real palacio, donde se vendían todos los días del año. Y además estaba el Corifeo: "donde no se repetían otras coplas que las de esta naturaleza, ni se componen las comedias de otro asunto que de la misma naturaleza". ${ }^{51}$ Algunas composiciones fueron muy perseguidas por las autoridades, como el famoso chuchumbé, bestseller de la colonia; en ellas se ataca al clero, al poder, a las nuevas costumbres, a las reformas borbónicas, etcétera. Velarde se queja en el proceso del gran número de compositores que había en México y en Puebla sin que fueran molestados, en cambio a él le había caído todo el peso de la ley. ¿Por qué?

Gálvez y sus aliados (Lorenzana, Fuero y Croix) sobrestimaron la función y la eficacia de las composiciones clandestinas, y los inquisidores, presionados por las autoridades virreinales e imperiales, convirtieron a Velarde en un chivo expiatorio y en un aviso para el resto de los rapsodas de la Nueva España. Es cierto que los versos del Poeta estaban preñados de alabanzas a los jesuitas, pero este sentimiento no podía cambiarse en un territorio con muchos afectos, y más cuando el rey no había comunicado las graves causas que le habían llevado a decretar la expulsión. En "Arma, arma, guerra, guerra". Velarde imagina un consejo de demonios que decide la persecución, difamación y exilio de los ignacianos. Sin duda, su atrevimiento va muy lejos, pues imagina la detención y salida de los padres por inspiración demoníaca, pero esta composición, tanto en su forma como en el contenido, no era nueva en el romancero popular castellano. El argumento de Velarde es muy viejo, y no suponía una amenaza para la estabilidad del régimen colonial. Esta claro que las autoridades lo sacrificaron ante la

trabajo de varios alumnos y colaboradores, estuvo dirigido por María Águeda Méndez, Fernando Delmar, Ana María Morales y Marxa de la Rosa. Como muestra de la riqueza de los depósitos inquisitoriales, véase Baudot, Georges y Méndez, María Águeda: La palabra condenada en el México de los virreyes. Antología de coplas y versos censurados por la Inquisición de México, Siglo XXI, México, 1997; y Méndez, María Águeda: Secretos del Oficio: avatares de la inquisición novohispana, El Colegio de México-UNAM-CONACYT, México, 2001. Yo mismo me he valido de los expedientes inquisitoriales para mi trabajo: “"Mas líbranos del mal. Amén”. Oraciones profanas y sátiras en el México Ilustrado", en Enriqueta Vila y Carlos Alberto González (comp.), Grafías del imaginario. Representaciones culturales en España y América (siglos XVI-XVIII), Fondo de Cultura Económica, México, 2003, págs. 203-237.

51 Defensa escrita de Velarde. "Expediente formado...”, AGN, Inquisición, 1522, exp. 3, f. 62v. 
impotencia de descubrir a otros autores de sátiras y escritos más importantes, como la antipastoral.

Si Velarde había compuesto versos en alabanza de los ignacianos, también era autor de declaraciones de amor al soberano. En el poema "A los que están caducando" señala: "En fin, yo como obligado/ vasallo leal constituido,/ refiero lo sucedido,/ mas no impugno lo mandado,/ que las traiciones de osado/ en mi lealtad no cupieron". Y en los versos sobre la llegada de las tropas, canta "el católico celo", "el caritativo ardor", el "paternal amor" y la "real magnificencia". No era Velarde un rebelde, pero como a tantos novohispanos la medida de la expulsión de los jesuitas le pareció un desatino. Necesitado de componer para comer, aprovechó el sentimiento de sorpresa y rechazo general a la expulsión para concebir los versos. Y cuando ya había pasado el impacto de la novedad y la clientela no pedía esas poesías, se produce la denuncia, que convirtió a nuestro poeta en un caso aleccionador.

Las coplas del poeta callejero producen miedo por su poder de intermediario o poseedor de la voz de la calle, de la opinión pública. Hay miedo a su libertad, a la falta de controles. Como ha señalado Roger Chartier, en el siglo XVIII hay una fuerte supervivencia de la circulación manuscrita de los textos literarios. Los libros impresos y autorizados conviven con numerosos textos prohibidos o secretos. Son textos contra el poder, satíricos, de magia o sexo. Pero junto a esta temática "hay géneros literarios clásicos para los cuales la antología manuscrita es una forma ordinaria, por ejemplo, la poesía". ${ }^{22}$ Versos de amor, espirituales, religiosos o de costumbres circulan en grupos más o menos amplios de lectores que comparten el mismo modelo cultural. En algunas ocasiones, es el autor el que elige la forma manuscrita, pues supone un mayor control sobre la forma de su obra y sobre el público. En otras, la forma manuscrita es el refugio de lo prohibido y lo secreto: la forma de eludir los controles oficiales, los costes de edición y los lentos trámites. ${ }^{53} \mathrm{Y}$, por último, están los usos comerciales de esos manuscritos. Dentro de este grupo estaría nuestro autor, que vivía de y por la poesía y las cartas de encargo. La circulación de sus obras estaba restringida a un pequeño grupo de habitantes de la ciudad de México, quienes compartían un mismo universo de interpretación. Sin duda, estamos

52 Chartier, Roger: Cultura escrita, literatura e historia. Conversaciones con .... Edición de Alberto Cue. FCE, México, 1999, p. 22.

53 Moureau, François: De Bonne main. La communication manuscrite au XVIIIe siècle, Universitas, Paris, y The Voltaire Foundation, Oxford, 1993. 
ante uno de los ejemplos más interesantes de la circulación del manuscrito en la colonia, ${ }^{54}$ pues marcaría, según Pablo González Casanova, el principio de la opinión pública en México:

"La expulsión de los jesuitas de Portugal, España y México da lugar a que circulen profusamente innumerables papeles y versos contra los reyes, contra el Papa y contra el gobierno en general [...] El principio de autoridad cae por los suelos en medio de las iras y el desconcierto. Aunque se mantengan las viejas categorías religiosas, y se hagan las críticas en nombre de Dios, del Rey o de la religión, se discute en forma tan violenta y apasionada que a la postre se adquiere una vigorosa conciencia política, que es la base de una opinión pública antes inexistente. Esta opinión pública revela la ampliación del horizonte crítico y es la negación del chismorreo, del rumor, de la sátira de cocina y covacha". ${ }^{55}$

Del caso de Velarde, me interesan más los aspectos extra-literarios que poéticos. Dejo para los expertos los mecanismos teóricos y las figuras literarias. No tenemos muchos datos sobre los compradores de las obras (solo dos: el cura de Coyoacán y el denunciante), ni tampoco sobre la recepción de la obra. No hay duda que tenían un mensaje ideológico: el alabar a los jesuitas y el criticar a los que hicieron la expulsión, pero no está claro que Velarde influenciara en la opinión pública. A pesar de ello, creo que el proceso inquisitorial permite obtener datos sobre la vitalidad de la poesía popular, difícil de documentar, sobre la escritura y difusión de una obra literaria y nos ofrece datos interesantes de cómo fue recibida la orden de expulsión de los jesuitas de la Nueva España.

54 Sobre los diferentes usos del manuscrito en la Inglaterra del siglo XVII, Love, Harold: Scribal Publication in Seventeenth Century England, Clarendon Press, Londres, 1993.

55 González Casanova, Pablo: La literatura perseguida en la crisis de la colonia, Cien de México, México, 1986, p. 87 [1ª edición, 1958]. 


\section{LOS VERSOS DE VELARDE}

\section{A la arma, a la arma, guerra, guerra ${ }^{56}$}

A la arma, a la arma, guerra, guerra, dijo el infernal vestiglo, Príncipe de las Tinieblas, fatal e infeliz caudillo de las diabólicas tropas, de los profundos abismos. Guerra, guerra, repitió, con tanto estruendo y tal ruido, que al punto salieron todos sus vasallos y rendidos. ¿Contra quién, le preguntaron, hemos de acertar los tiros? Él entonces, enojado y entre furias combatido, les dijo: ¿no lo sabéis? ¿Tan grande es vuestro descuido, que cuando os miráis vencer, ignoráis los enemigos? ¿Contra quién me preguntáis? Pues ¿qué decís? ¿No habéis visto a esos que con negro traje, en sus sombras escondidos, son para darnos asombro, soldados del siempre invicto, fuerte y poderoso brazo que les da aliento crecido para ser más que hombres, ángeles, por su infatigable espíritu, por su continua tarea, del celo caritativo, por su oración fervorosa, por su dulce amable estilo, por su magnanimidad en dar el pan y el abrigo a la viuda, a la doncella, al vergonzante, al mendigo, haciéndose tan amables que son un dulce atractivo de almas y de corazones, pues se los llevan consigo, quitándonos el derecho de tantos que ya cautivos teníamos esclavos nuestros en número de precitos, siendo ya predestinados los que obstinados han sido? Estos hacen nuestra contra a más de grandes perjuicios, que nos hicieron formando el libro del Catecismo, donde la teología toda está en pedidos concilios, siendo una mística plana, un espejo en que clarísimo se le trasluce al cristiano el cumplimiento preciso de su justa obligación, teniendo viejos y niños

56 Existen dos versiones. La primera en AGN, Inquisición, 1522, exp. 3, ff. 17r-26r; y la segunda en los ff. 30r-35r. Esta última añade algunos versos más, que añado en cursiva. 
dirección para saber huir del eterno castigo y buscar el bien eterno, cosa que tanto he sentido. Yo he puesto doble trabajo para ver si así consigo perturbar a los cristianos para que rabien conmigo, más por diligencias que hago y por más que me fatigo, no todos me creen a mí, viendo tan claros avisos que de los padres jesuitas han tomado a pesar mío. Mirad si tengo razón de llamaros y deciros guerra contra éstos, que son nuestros crueles enemigos. ¿Qué me respondéis vasallos? Mirad que rabio y me aflijo. Gran señor (responderían sus secuaces malditos) no te aflijas, que ya estamos de tu intención advertidos, y todos como nos veis dispuestos y prevenidos para buscar nuevas trazas y modos de confundirlos. Presto verás derrotados, arruinados y destruidos, a esos que tanto te niegan y tan contrarios te han sido. Esperad, señor, victorias, pues ya todos te decimos que los verás castigados, ultrajados y abatidos.

A eso les respondería el fiero dragón maligno: ¿cómo puede ser todo eso, si son de Dios tan amigos, y de los buenos cristianos son amados y aplaudidos?

Señor, por esa razón, unánimes te decimos: no temas eso porque más fácil lo conseguimos, pues permite el mismo Dios sean los justos perseguidos. Sembraremos iqué cizañas! en los pechos más benignos, porque respiren rencores, acreditando fingidos en estos falsos informes de engañosos fementidos. Haremos que el más prudente, el más católico y pío, el más docto y más capaz, el más sabio y más científico, el más recto y justiciero, el más manso y compasivo, el más paternal amparo y el más eficaz auxilio que a su favor en lo humano tenían, decrete al proviso salgan todos desterrados de todo su real dominio, sin honra, opinión y fama, de sus bienes desposeídos, confusos y avergonzados, pues donde son conocidos por hombres muy ajustados, virtuosos y recogidos, verás andar en concejos de asambleas y corrillos y en opiniones su crédito, pues de su daño advertidos unos dirán que quizá los padres fueron judíos, otros que quizá traidores y otros que habrán también sido herejes, pues de mil modos les han de cortar vestidos. 
Y, en fin, los verás salir vergonzosos y corridos, con más tropelía que un reo sentenciado de delitos, pues despedirse siquiera no les será permitido, y los verás dominados del lobo, el mulato, el chino, pues muy de prisa saldrán de soldados guarnecidos. ¿Qué dirás? ¿Estás contento con lo que aquí te hemos dicho? Y como que sí lo estoy con lo que habéis prometido, y para que así lo creáis tomad mis brazos amigos. Llegad, llegad a mis brazos, pues que tanto los estimo, para recibir en ellos a todos cuantos han sido instrumento de sus daños y ultraje que tanto estimo. Cante victoria el infierno, victoria pues que ha vencido esas que fueron columnas de aquel tan fuerte edificio del católico hemisferio que yo destruir determino. ¡Ea amigos! A derribar esos torreones altivos de virtudes, que formaron con documentos divinos. Formemos en su lugar la Babilonia de vicios, que así caerán los mortales a mis pies desvanecidos. ¡Qué gran cosecha esperamos cogiendo almas a racimos! Demos, pues, tan cruda guerra, en el empeño metidos, que es tiempo de que restaure el infierno lo perdido, pues ya faltan en la iglesia los que fueron aplaudidos, en predicar eficaces por los muchos convertidos, en confesar muy celosos, de la conversión solícitos, pues con este santo fin salían siempre compasivos a deshoras de la noche, aunque llovieran granizos y aunque los atormentaran los nevados torbellinos. Han sido estos tan tenaces en predicar, que imagino que hacen empeño el morir predicando como Cristo, mas yo les daba batalla con muy acervos martirios de fuego, de agua o de sangre, que inventaba vengativo, y ellos sin tener temor de las puntas y los filos de lanzas, dagas y espadas, o de incendios muy activos, o de las furiosas olas de pozos, mares y ríos, sin el más mínimo miedo a tan acervos martirios, solo ad maiorem Dei Gloriam predicaban encendidos de crecida caridad, consolando al afligido, hasta llegar a entregar a Dios su abrazado espíritu. Esto hacían en nuestra contra, y mucho más que no digo, y en premio de su trabajo démosles su merecido, sigamos dándoles guerra que, aunque los hemos vencido, 
pretendo no haya ciudad, villa, pueblo o cualquier sitio, donde los quieran jamás ni que sean bien recibidos, y en donde quiera que lleguen, quiero que sean perseguidos, $y$, pues ya van desterrados, corriendo en esos caminos, cerremos todas las puertas porque no sean conducidos otra vez a los lugares de donde ya están excluidos, que entonces nos burlarían y quedaríamos corridos. Mas para que no quedemos burlados, como decimos, vamos y los corazones de todos y sus amigos tiremos a endurecer, que con eso conseguimos que nadie pida por ellos y los echen en olvido. Sigamos dándoles guerra a estos padres y a aburrirlos. Vamos haciéndoles burla y aturdámoslos a gritos, digámosles a corrida que ya todos os vencimos. Ya vuestra gran religión la acabamos y destruimos; ya os miramos por los suelos cuando antes tan aplaudidos. Ahora os traeremos rodando de tierra en tierra, afligidos, hasta que os desesperéis, que es el fin a que yo aspiro. Con eso conseguiré que vengan acá conmigo, que yo y todos mis vasallos saldremos a recibirlos $\mathrm{y}$ os tendremos un banquete de metales derretidos, y una consonante música de clamores y gemidos, pues les prometo que todos seréis muy bien atendidos. Démosnos los parabienes, vasallos, pues conseguimos aniquilar a estos padres, que eran nuestros enemigos. Juguemos a la pelota con ellos, pues, ya rendidos, no podrán contrarrestar a votes tan repetidos. Denles un buen sotamano y un revés para que, unidos, de un rebote caigan juntos en los profundos abismos, pues nunca tendrán ni resto aquí sumergidos, resto no les quedará, pues se mirarán perdidos, tristes y desamparados por los siglos de los siglos, y pues ya tenemos brecha y tan ampliado el camino, no hay que estarnos perezosos, corramos aprisa amigos a pervertir a los justos que, según lo que imagino, pocos habrá que se escapen de rabiar acá conmigo. Vamos, vamos a tentar al viejo, al mozo y al niño, al sacerdote, al señor, al prebendado, al ministro, al duque, al conde o marqués, al plebeyo, al negro o chino, y a todas almas aquellas que seguían aquel camino, que les abrían los jesuitas con su ejemplo y ejercicios, 
que escribió su gran patriarca san Ignacio en un librito.

¡Qué diera yo por borrarlo! Cuanto soy y cuanto he sido. Pues, señor, con tu licencia, ya nos vamos prevenidos de asechanzas y maldades, con prisiones y con grillos, para traerte a los cristianos presos para tu servicio. Aguardad, tened vasallos, ¡oh mal aya mi destino!, que un punto de gravedad se me pasaba deciros. Mirad que quiero que todos y cada uno esté advertido de tentar bien a los hombres para ver si así consigo que no falte un mal cristiano docto, rudo o entendido, que diga que no es tal santo san Ignacio, y que ha sabido que el que lo canonizó fue un antipapa fingido. Con eso titubearán los poco o nada advertidos, y aún los capaces también no atinarán, confundidos. Empeñaos bien en hacer esto que os encargo, amigos, que pienso así conseguir el que dejen el librito de Ejercicios, pues por él van muchos al cielo empíreo. Vamos presto por dejar a todo el mundo destruido, de modo que los vivientes digan en futuros siglos, cuando acaso transitaren de la América los sitios, aquí fue la gran ciudad de México, el nunca visto, ya tan sólo en los cimientos se ven algunos vestigios, aquí monedas labraban, que ya no las conocimos. Muy noble cuentan que fue, según procesos antiguos, en los anales del tiempo que la fama dejó escritos. Cumplióse la profecía que la dictó a Carlos quinto Teresa, de que este reino a sus dueños primitivos sin duda habría de volver; así los viejos lo han dicho. Esto dirían y yo quiero mirarlo todo cumplido.

A la arma, a la arma, guerra, guerra, sigamos nuestro designio, y hagamos tiemble la tierra, cual si tuviera sentidos, viendo ultrajar a estos padres, soldados de Jesucristo, y que hagamos muchas almas para el eterno martirio, maldiciendo a su criador con rabia y furor crecido, aborreciendo a la Virgen, ¡qué gozo tengo al decirlo! Lloren, lloren los vivientes, esparzan tiernos gemidos, escriban con sangre roja como allá en San Luis se ha escrito. Con sangre escribir la historia del suceso referido, muchas vidas ha costado lo que es tan a gusto mío. Fin 


\section{“Fue la Compañía non plus". Versión larga ${ }^{57}$}

Fue la Compañía non plus por su ciencia y energía, y hoy se mira a buena luz de Jesús la Compañía acabada en buena cruz.

Lloren a mares vivientes la desgracia sucedida, lloren ver tan abatida de la gracia las corrientes con lágrimas suficientes que rabie el fiero Albetrus, fiado siempre en que Jesús es juez de ciencia divina y en enseñar su doctrina fue la Compañía non plus.

Llora ciudad americana la violencia y el rigor con que te metió en temor la intolerable cuartana de aquella gente inhumana que con tanta tiranía ultrajó la Compañía y aquellos benditos padres, que eran de gracia raudales por su ciencia y energía.

Lloran niños la enseñanza y explicación de doctrina que en voz dulce y peregrina recibían con vigilancia de los padres que en abansa siguen en todo a Jesús, aunque acá todo dio luz, el ser no se le quitó, y en ellos lo que operó ya se mira a buena luz. Todo en ellos floreció por disposición divina y también por ser doctrina el cielo se condolió.

La tierra toda tembló de ver tanta tropelía que hicieron la noche día los ministros inhumanos para destruir muy ufanos de Jesús la Compañía.

En fin, todos los vivientes, según se mira el indicio, háganse el cargo y el juicio son presagios suficientes, pues por las cosas presentes, que hoy vemos tan a la luz, nos da a conocer Jesús que fue en nuestra redención su vida, muerte y pasión acabada en buena cruz.

Los jesuitas afligidos por aquesos mares van, de esto todos son testigos, y con el tiempo verán los que son sus enemigos.

Lloren ojos sin cesar verse sin la Compañía, lloren que llegará el día que la vuelvan a mirar. Entonces se ha de acabar el ver tantos fugitivos, pues que los tiene[n] oprimidos la fuerza de su pesar, cuando vuelven a mirar los jesuitas afligidos.

Que esto que mis oídos oyen contra estos benditos padres, testimonios a millares de las lenguas de atrevidos,

57 AGN, Inquisición, 1522, exp. 3, ff. 26r-28v. 
ellos serán confundidos, sin poderlo remediar, y entonces oídos oirán de los mismos enemigos, como dicen que rendidos por aquesos mares van.

Boca ya no me ha quedado, pues me la mandan cerrar, silencio boca guardar porque te costará caro. Me miro ya desbocado a la punta de dos filos, y luego escuchan mis oídos que detenga el pensamiento, que no miento, que no miento, de esto todos son testigos.

\section{“Fue la Compañía non plus". Versión breve ${ }^{58}$}

Fue la Compañía non plus por su ciencia y energía, y hoy se mira a buena luz de Jesús la Compañía acabada en un ¡Jesús!. Hado cruel, bien tus indicios expresan en desventuras cómo siempre a las alturas amenazan precipicios. Vidas han costado y juicios la falta de tanta luz, la Compañía de Jesús, emporio de tanta ciencia, pues por virtud y elocuencia fue la Compañía non plus. A tal extremo llegó lo acervo de este tormento, que de puro sentimiento hasta la tierra tembló. Todo corazón vistió color de melancolía, diciendo la Compañía para siempre desterrada, tan digna de ser llorada por su ciencia y energía. Llora americano polo tu desgracia en este día, porque sin la Compañía bien te puedes llorar solo. Manifiesta fino dolo, abrázate de la cruz, pide consuelo a Jesús por tu Compañía extrañada, que antes fue pronosticada y hoy se mira a buena luz. En un lance tan atroz y en esta variable rueda, el consuelo que más queda es que se fueron con Dios, y así todos a una voz publiquen con hidalguía que a que esta santa energía por siempre con Dios está, pues ésta ha sido y será de Jesús la Compañía. En fin, Italia dichosa, al cielo gracias le das, porque breve te verás con los padres venturosa. Goza de la dicha, goza, de una ciencia que es non plus, regálate con la luz que por desgracia perdimos, una Compañía que vimos acabada en un ¡Jesús! Finis.

58 AGN, Inquisición, 1522, exp. 3, ff. 69r-69v. 


\section{Que crea de los jesuitas lo que ves ${ }^{59}$}

Que crea de los jesuitas lo que veo y no oiga a la malicia sus arrojos me aconsejan; más yo cerré los ojos y a ojos cerrados su[s] virtudes creo, porque un ciego palpara el devaneo de la falaz envidia y sus arrojos, mas la piedad resiste a sus enojos, la evidencia desmiente a su deseo, y aunque no fuera tanta se quedara dudoso en la razón de la porfía en lo mismo que dije, y me afirmara que a la piedad más fácil le sería que la culpa de ser culpa dejara, que culpada juzgar la Compañía.

\section{A los que están caducando ${ }^{60}$}

A los que están caducando, en los años que vivieron, pregunto si acaso vieron lo que hoy estamos mirando. La octava, solemne día, de aquel pan sacramentado, México, ¡qué alborotado!, triste sentimiento hacía, cuando llorando advertía que por Real Decreto y mando se extrañen, publicó el bando, las jesuitas religiones, llenando de admiraciones a los que están caducando. Los jesuitas desterrados, ¡válgame Dios!, ¡qué dolor! ¿Quién causó tanto rigor, más quién sino mis pecados? ¿Apóstoles aclamados estos varones no fueron? ¿La doctrina no impusieron? ¿Piadosos no la explicaron? ¿La teología no enseñaron en los años que vivieron? En fin, yo como obligado vasallo leal constituido refiero lo sucedido, mas no impugno lo mandado, que las traiciones de osado en mi lealtad no cupieron, sólo [a los] que encanecieron, viendo casos prodigiosos, sucesos tan lastimosos pregunto si acaso vieron. Los colegios guarnecieron en lance tan peligroso, y a cada uno religioso centinela le pusieron.

Las campanas no tañeron y los templos resguardando, con guardias fueron sitiando para confundirnos más, pues no se ha visto jamás lo que hoy estamos mirando. Regimientos repartidos andan alerta rondando, en día y noche prevenidos, a el vulgo atemorizando de órdenes y armas vestidos Fin.

59 AGN, Inquisición, 1522, exp. 3, f. 35r.

60 AGN, Inquisición, 1522, exp. 3, ff. 36r-37r. Otra copia en ff. 71r-71v. 


\section{En armas con qué primor ${ }^{61}$}

En armas con qué primor brilla el católico celo de nuestro rey y señor que mil años guarde el cielo.

Como sol esclarecido que en ambas esferas luce, distintos rayos conduce de soldados que han venido, en los que ha resplandecido el caritativo ardor de su paternal amor, mostrándonos la potencia de su real magnificencia en armas, ¡con qué primor!

Como es nuestro soberano, se ha empeñado en defender no nos lleguemos a ver en poder de algún tirano, y con ánimo cristiano formó de armas su desvelo, un lucido Mongibelo ${ }^{62}$ en el que con claridad de su sacra majestad

luce el católico celo

En las nuevas compañías, con el garbo más pulido, marcha cada uno vestido de luto con chirimas, diciendo ambas energías como aquel real resplandor, carbón volveré al traidor que desleal se conspirare y las leyes no observare de nuestro rey y señor.

En lo blanco y encarnado, con vueltas negras se advierte que a un tiempo paz, sangre y muerte, muestra su brazo esforzado contra el enemigo osado siendo rayo paralelo que en cenizas en un vuelo lo dejara convertido este sol vello y lucido que mil años guarde el cielo

\section{¿Cómo estás?, ¿Cómo te va niña con el sarampión?³3}

¿Cómo estás?, ¿cómo te va niña con el sarampión? Mírame toda escamada, que estoy echa un camaleón.

Si es aprehensión o es idea, háblame con claridad, dime la pura verdad, ¿es cierto que estoy muy fea? ¡Ay niña cuando me vea aquel dedo!, ¡qué dirá! De risa se tenderá, después que no le he debido que me diga de fingido ¿cómo estás?, ¿cómo te va?

Pues niña, por vida mía, que para decirlo todo, te has levantado de modo que ya no te conocía.

61 AGN, Inquisición, 1522, exp. 3, ff. 36v-37r.

62 Mongibelo o Mongibello, nombre cultista con que en italiano se llamaba al volcán Etna.

63 AGN, Inquisición, 1522, exp. 3, ff. 36v-37r. 
Te has puesto que es herejía, sin nada de perfección, de esta hecha tu presunción y tu garbo feneció, pues todo se te acabó niña con el sarampión.

Hermanita considera como puedo haber quedado, si de día y de noche he andado a brinquitos de carrera. Ya estoy con tanta chorrera, toda mi cama chorreada, y yo tan desfigurada, tan flaca y tan granujienta, y si no hermanita tienta, mírame toda escamada.
Me hago, niña, sin cesar los remedios a montones, pero las evacuaciones no hay remedio de parar, y sólo siento el quedar como el gallo de Morón, porque sin apelación creo que me ha de aborrecer mi cuero en llegando a ver que estoy hecha un camaleón.

En fin, niña (quedo viuda), pues si él me va a visitar, al tiempo que el pujo acuda no podré disimular que se me sale la ayuda.

\section{Quien pensara que el gran blanco ${ }^{64}$}

Quien pensara que el gran blanco cordial que bajó del cielo, un ardentísimo celo quiera reducirlo a estanco, cuando liberal y franco para excitarnos la gana de esta vianda soberana y magnífico convite el pontífice permite la comunión cotidiana.

No es de derecho divino, como algunos han pensado, este sabroso bocado que de allá del cielo vino. En la escritura imagino muy versado no estará quien no supiere que allá de Israel en las correrías el pan de todos los días fue para el pueblo maná.

Figura del sacramento fue y todos advertirán que el eucarístico pan de vida es y entendimiento de gracia. Confiere aumento y de gracia un solo grado, según lo dejó asentado el Angélico Doctor. Es un bien tan superior que excede a todo lo criado.

Luego siendo incontroverso que un solo grado de gracia por su virtud y eficacia es más que no el universo, el argumento en converso

64 AGN, Inquisición, 1522, exp. 3, ff. 35r-36v. 
tiene una fuerza excesiva, que el que impide que reciba el cristiano al Dios de amor, de una dicha que es mayor que todo el mundo le priva.

$\mathrm{Ni}$ es esto decir que todos lleguen cada día a la mesa, porque esto de la pureza tiene sus grados y modos, pero el que huye de los lodos, de la culpa y recta vía, camina, siga su guía (esto es, a su confesor) y con respeto y temor éste llegue cada día.

Ni puede haber regla fija a todos, y es conveniente buscar un docto, prudente confesor que le dirija, por su dictamen se rija, descubriendo su conciencia, estando en la inteligencia que en lugar de Dios está: él le determinara ya más, ya menos frecuencia.

Casados y comerciantes, relatores y abogados, y otros que están ocupados con oficios semejantes, será conveniente que antes se dispongan con limpieza y con la mayor pureza posible para llegar no con frecuencia al manjar de tan sacrosanta pureza.

Pero es preciso advertir a todos, que es lo mejor de un discreto confesor los dictámenes seguir, no a todos se ha de medir por un rasero importuno, y así es consejo oportuno el que el director dará, que prudente dispondrá lo que convenga a cada uno.

Mas la[s] almas religiosas que a su Dios se han ofrecido, y por Él tanto obtenido título de sus esposas, muchas mujeres virtuosas, muchos virtuosos seglares que son hombres ejemplares, lleguen con paso veloz y reciban de su Dios beneficios a millares.

Dicen los escrupulosos: yo no llego con frecuencia, porque tengo en la conciencia mil pecados onerosos. Estos pobres congojosos es el remedio eficaz no hacerles caso jamás y por más que lo encarezcan intimarles que obedezcan al confesor y no más.

Otro dice no soy digno, imitando al centurión, esa es clara tentación del espíritu maligno. Es nuestro Dios tan benigno que el deseo le satisface de ser digno y se complace, y aún tengo más que decirle, que Dios para recibirle no busca dignos, los hace.

Que si dignidad buscara pienso que no la hallaría sino en su madre, María, 


\section{SALVADOR BERNABÉU ALBERT}

Ave más que el Fénix rara, pero si bien se repara aunque es sublime su altura, aunque es tan santa y tan pura y su gracia tan intensa, pero es la distancia inmensa que hay de Dios a la criatura.

Otro dice: yo no llego, por tibieza o desvarío, que es decir yo tengo frío y llegar, no quiero al fuego. Que es bueno el temor no niego, pero sea reverencial, sea temor pero filial, mas no sea temor servil, que aqueste es de ánimo vil, es otro de pecho leal.

Otro dice por aprecio: me abstengo que, en conclusión, la mucha conversación es causa de menosprecio. Este alegato es muy necio, que de los hombres se entiende, no de Dios, que el alma enciende, cual fuego consumidor, y que se abrace en su amor eso justo que pretende.

A la mística doctora alegan, la cual decía: confesaré cada día, ¡ojalá y fuese cada hora! Mas recibir al que mora Dios con nosotros justo es, que no pase solo un mes y otro, y otro sin pasar, porque basta comulgar al año solo una vez.

De mi intento no es extraño lo que otro santo decía, el pan es de cada día ¿por qué le tomas cada año? Que todos salgan de engaño es lo que mi afecto aprecia, no es mi presunción tan necia que no le sujete humilde, voz, ápice, jota o tilde, a la Santa Madre Iglesia.

Recibido el 5 de junio de 2005 Aceptado el 15 de septiembre de 2005 